\title{
Adjusted barrier management to improve glass eel migration at an estuarine barrier
}

\author{
Ans M. Mouton*, Maarten Stevens, Tom Van den Neucker, David Buysse, \\ Johan Coeck
}

Research Institute for Nature and Forest (INBO), Kliniekstraat 25, 1070 Brussels, Belgium

\begin{abstract}
European eel Anguilla anguilla (L.) populations have declined dramatically during the last decades and are now among the most critically endangered fish populations in Europe. The limitation of upstream migration of glass eels is considered to be one of the key factors reducing eel populations. The migration of eels in their juvenile stage (glass eels) was studied, and options to improve eel passage at a tidal barrier complex at the mouth of the Yser River, Flanders, Belgium, were assessed. Glass eels were sampled during tidal rise with stow nets and lift nets to analyse their distribution over the study area, while a fyke net was used to evaluate the impact of limited barrier opening on glass eel migration. Support-vector machine-based analysis of the lift net data indicated that migrating glass eels are attracted by the freshwater flow leaking from the barriers, whereas other variables such as the sampling location only had a weak influence on the glass eel density. Limited barrier opening during tidal rise appeared to be a cost-efficient and effective mitigation option to improve upstream glass eel migration without significant intrusion of seawater. Adjusted barrier management could often be implemented and applied on numerous tidal barriers. Therefore the results of this paper are of interest to a wide range of river managers and stakeholders and may contribute to the conservation of many eel populations.
\end{abstract}

KEY WORDS: European eel · Anguilla anguilla (L.) · Estuary management · Tidal barrier · Glass eel $\cdot$ Fish migration

Resale or republication not permitted without written consent of the publisher

\section{INTRODUCTION}

For several decades, a substantial decline of the European eel Anguilla anguilla (L.) has been observed throughout Europe (Dekker 1998, 2000, Bonhommeau et al. 2008b) and the species is now considered as a critically endangered European fish species (Buysse et al. 2008). Various causes of this trend have been reported, such as chemical water quality, physical habitat conditions, predation and migration barriers (White \& Knights 1997, Knights 2003), body condition (Bureau Du Colombier et al. 2007), parasites (Audenaert et al. 2003), oceanic change and climate change (Knights 2003, Friedland et al. 2007, Bonhommeau et al. 2008a,b, Kettle et al. 2008). To aid the conservation and recovery of Euro- pean eel stocks, the European Union recently adopted a Council Regulation (EC no. 1100/2007). The Council Regulation requires a management system that ensures $40 \%$ escapement of the spawning stock biomass, defined as the best estimate of the theoretical escapement if the stock had been completely free of anthropogenic influence.

Flanders, the northern part of Belgium, is considered an important area for eel growth and adult reproduction due to its high density of lowland rivers, canals, brooks and ditches. The chemical water quality of the Flemish rivers has improved significantly over recent decades due to intensive wastewater treatment efforts and the implementation of fertiliser standards. Furthermore, the European eel has relatively wide physical habitat preferences and 
thus most of the Flemish water bodies are suitable eel habitats, which is reflected by the wide distribution of the species in this area (available from Research Institute for Nature and Forest (INBO); vis.milieuinfo. be). Consequently, river managers now focus on the mitigation of predation and migration barriers to stimulate eel populations (Stevens et al. 2009).

Several authors agree that the upstream migration of eel, particularly at the juvenile stage (unpigmented $0+$ eel, body length ranging from 6 to $8 \mathrm{~cm}$ and hereafter called glass eel), is one of the crucial bottlenecks in the conservation of eel populations (White \& Knights 1997, Feunteun et al. 1998, Briand et al. 2005, Bult \& Dekker 2007, Laffaille et al. 2007). Leptocephalus larvae emerging from the Sargasso Sea spawning grounds migrate to Europe along the Gulf Stream and transform into glass eels once they reach the continental shelf. These glass eels often do not reach European freshwater habitats due to migration barriers such as dams, weirs and sluices. Reduced glass eel recruitment may therefore be a significantly limiting factor in achieving escapement targets of adult eel migrating to their spawning grounds (known as silver eel).

Many European estuaries contain man-made barriers (e.g. for flood protection) often resulting in sharp seawater to freshwater transitions with the absence of a brackish tidal zone. Even though such transitions cause no osmoregulatory problems in glass eels (Wilson et al. 2004, 2007) and some glass eels may eventually succeed to migrate upstream, their migration may be delayed and the risk of predation increased. The resulting energy losses may entail behavioural shifts that limit further upstream migration (Edeline et al. 2005, 2006, Bureau Du Colombier et al. 2007). Although the Flemish government is currently attempting to stimulate eel population growth by restocking inland waters with glass eels, previous research showed that this approach may not only be unsustainable and expensive but also increase the distribution of harmful parasites (Audenaert et al. 2003). Consequently, integrated management options are needed that facilitate the upstream migration of local glass eels.

This present study analysed the environmental factors affecting glass eel migration at 5 estuarine barriers located in the Yser River estuary in Flanders, Belgium. The distribution of glass eels over the 5 river mouths was monitored and options for adjusted barrier management were investigated. The results of this paper may not only provide valuable insight into the environmental factors affecting estuarine glass eel migration but also assist river managers to efficiently operate estuarine migration barriers.

\section{MATERIALS AND METHODS}

\section{Study area}

Glass eel migration was studied between March and April 2009 at the mouth of the $76 \mathrm{~km}$ long Yser River, a navigable lowland river in Flanders, the northern part of Belgium (Fig. 1). The Yser basin covers an area of $1101 \mathrm{~km}^{2}$ and $32 \mathrm{~km}$ of the river is located in France. The basin is known as an important area for European eel, providing valuable habitats for growth and development (Denayer \& Belpaire 1996).

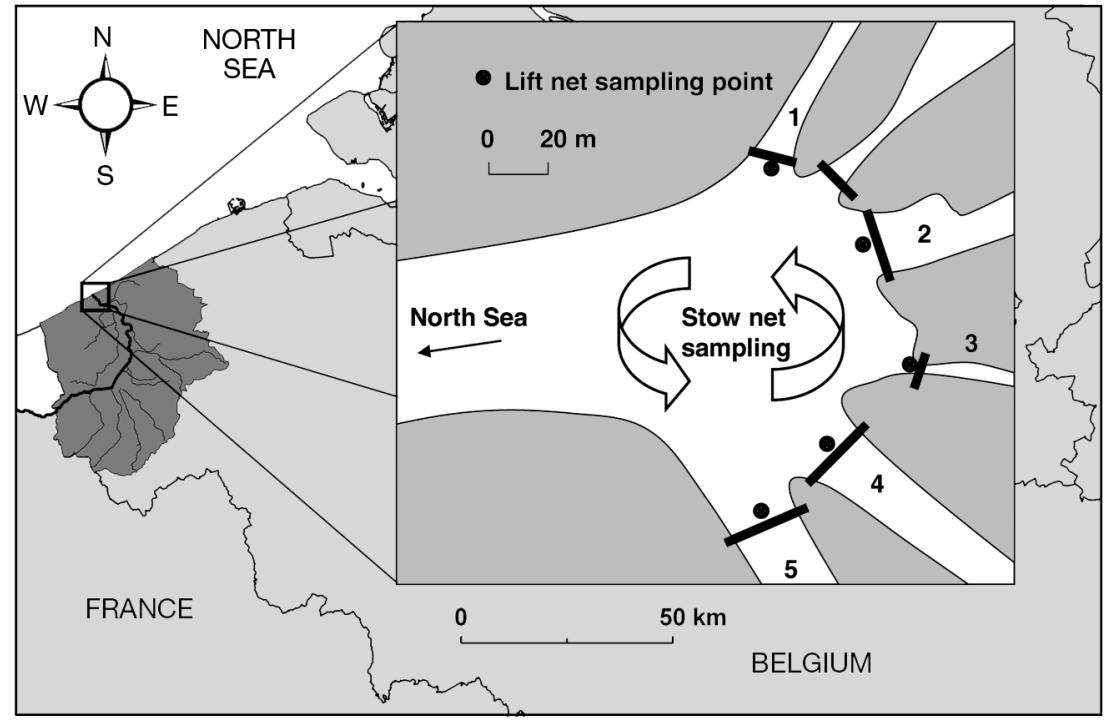

Fig. 1. Locations of the 5 sampling sites near barriers (black bars) at the mouth of the Yser River (inset) in Flanders, Belgium: (1) Nieuw Bedelf, (2) Nieuwendamme stream, (3) Yser River, (4) Channel of Veurne, and (5) Channel of Duinkerke. Stow net sampling was conducted in the basin downstream of the barriers, lift net samples were taken downstream of Barriers 1 to 5 and fyke sampling occurred upstream of Barrier 3. The sixth stream (between Barriers 1 and 2) was blocked by a sluice; this barrier was not comparable with the others and was omitted. Dark grey area is the river catchment 
At the river mouth, 6 different streams join in an artificial basin located about $3 \mathrm{~km}$ from the sea (Fig. 1), each stream being blocked by 3 to 8 tidal barriers. The barriers can be lifted vertically and are currently operated to avoid inflow of seawater during tidal rise for agricultural, environmental, flood protection and recreational reasons. The barriers are opened during low tide and closed once the seawater level approaches the water level upstream of the barrier. This equalisation of water levels generally occurs between 2.5 and $1.5 \mathrm{~h}$ before high tide. The volume of the freshwater outflow depends on the buffer capacity needed to avoid flooding. Flooding risk is continuously estimated based on the predicted runoff further upstream of the barrier. Consequently, depending on precipitation, different freshwater volumes are discharged at the 6 river mouths. The average flow over the last $15 \mathrm{yr}$ was $10.19 \mathrm{~m}^{3} \mathrm{~s}^{-1}$ while peak flow was $51.22 \mathrm{~m}^{3} \mathrm{~s}^{-1}$ and base flow $0.8 \mathrm{~m}^{3} \mathrm{~s}^{-1}$ (Hydrological Information Centre, Flanders Hydraulics Research; www.waterstanden.be). Flow is measured about $4 \mathrm{~km}$ upstream of the barrier where it is similar to the flow at the barrier.

Glass eel migration was studied at 5 of the 6 streams joining the tidal basin. The sixth stream is blocked by a sluice and thus this barrier type was omitted as being not comparable. The stony river bed structure directly downstream of the barriers did not vary substantially over the different streams since this area was artificially created.

\section{Data collection}

Glass eels were caught between March and April 2009 during the tidal rise of 12 tidal cycles, hereafter referred to as sampling events 1 to 12 (Table 1). The first 6 sampling events alternated between day and night and were conducted on 3 consecutive days between new moon and the first quarter. During the next $4 \mathrm{~d}$ no samples were taken because high tide occurred during twilight. The last 6 sampling events were conducted on 6 consecutive nights, the first 2 of which were situated between the first quarter and full moon, the 3rd coinciding with full moon and the last 3 occurring between full moon and last quarter. Spring tide occurred $5 \mathrm{~d}$ before the 1st sampling event, neap tide $1 \mathrm{~d}$ after the 6th sampling event and spring tide occurred again during the 11th sampling event. There was no opportunity to test the impact of the lunar cycle on glass eel densities since only one lunar cycle could be sampled during the glass eel migration period. All lights surrounding the sam- pling area were switched off during the nocturnal samplings. No significant variations in water quality or conductivity of the 5 streams were observed during the sampling period (Flemish Environment Agency; www.vmm.be). The weather was dry and water temperature, ranging from 7.4 to $7.8^{\circ} \mathrm{C}$, was similar for all streams, while no substantial changes in seawater temperature were observed during the sampling period.

Three different sampling techniques were applied: lift net, stow net and fyke net sampling (Table 1). At the barriers of the 5 studied streams, glass eels were sampled with lift nets with an opening of $1 \times 1 \mathrm{~m}$, length of $1 \mathrm{~m}$ and mesh size of $1 \mathrm{~mm}$. These nets were put on the bottom at the seaward side of the barriers and lifted simultaneously after $3 \mathrm{~min}$. The nets were emptied, and the glass eels were counted and kept in a reservoir. The seawater level, time and water level upstream of the barrier were monitored each time a net was lifted. Based on the seawater level, the volume sampled could be calculated, while the difference between the water levels at both sides of the barrier was used as a metric for the amount of freshwater leaking through the barrier.

Two stow nets that were $2 \mathrm{~m}$ long with a net opening of $0.5 \times 0.5 \mathrm{~m}$ and a mesh size of $1 \mathrm{~mm}$ were dragged along both sides of a small boat in the artificial basin. Samples were taken in an area of approximately $5000 \mathrm{~m}^{2}$ by dragging nets clockwise in a circle parallel to and approximately $40 \mathrm{~m}$ from the banks of the basin. These nets sampled glass eels occurring in the top layer of the water column, while

Table 1. The 12 different sampling events, the time these events occurred (day or night) and the applied sampling techniques. For fyke nets, samples were taken upstream of the barriers: either single samples, double samples (one each side of the channel) or multiple samples in consecutive 15 min periods throughout the tidal cycle. $\mathrm{x}$ : sampling technique was used for that sampling event

\begin{tabular}{|lcccc|}
\hline $\begin{array}{l}\text { Sampling } \\
\text { event }\end{array}$ & Occurrence & $\begin{array}{c}\text { Lift } \\
\text { net }\end{array}$ & $\begin{array}{c}\text { Stow } \\
\text { net }\end{array}$ & $\begin{array}{c}\text { No. of fyke } \\
\text { nets used }\end{array}$ \\
\hline 1 & Day & x & x & 1 \\
2 & Night & x & x & 1 \\
3 & Day & x & x & 1 \\
4 & Night & x & x & 1 \\
5 & Day & x & x & 1 \\
6 & Night & x & x & 1 \\
7 & Night & x & x & 2 \\
8 & Night & x & x & 2 \\
9 & Night & x & x & 2 \\
10 & Night & & & Multiple \\
11 & Night & & & Mulitple \\
12 & Night & & & Multiple \\
\hline
\end{tabular}


the total volume sampled was calculated based on a propeller flow meter (model 2030R, Eijkelkamp) attached to the net openings. During the last $3 \mathrm{~h}$ before high tide, glass eels were caught during consecutive samplings of $15 \mathrm{~min}$ duration. After each sampling, the nets were emptied, and glass eels were counted and kept in a reservoir on the boat.

At the upstream side of one of the barriers of the mouth of the Yser River, a fyke net with an opening of $2.0 \times 2.1 \mathrm{~m}$, a length of $10.5 \mathrm{~m}$ and a mesh size of $1 \mathrm{~mm}$ was attached and directed towards the sea. The fyke covered the entire barrier opening and thus allowed sampling of all migrating glass eel. During tidal rise, the barrier was lifted $0.1 \mathrm{~m}$, allowing seawater to flow upstream and enabling glass eels to migrate into the Yser River. The difference between water levels at both sides of the barrier was monitored continuously during each sampling event. Based on this water level difference, the flow was calculated following the HEC-RAS (USACE; www. hec.usace.army.mil) approach for discharge estimation under lift gates. If the discharge was unaffected by the downstream tailwater, it was computed with:

$$
Q=C W B \sqrt{2 g H}
$$

where $Q$ is the discharge under the barrier $\left(\mathrm{m}^{3} \mathrm{~s}^{-1}\right), C$ is the discharge coefficient, normally 0.5 to 0.7 and considered dimensionless, $W$ is the width of the barrier opening $(\mathrm{m}), B$ is the height from the spillway invert to the bottom of the barrier (m), $g$ is the gravitational constant $\left(\mathrm{m} \mathrm{s}^{-2}\right)$ and $H$ is the head from the spillway invert at the barrier to the upstream energy grade $(\mathrm{m})$. When the water level upstream of the barrier divided by the headwater energy $\mathrm{H}$ ranged between 0.67 and 0.79 , the transition equation was applied:

$$
Q=C W B \sqrt{2 g 3 H}
$$

while the orifice equation was applied if this ratio exceeded 0.79:

$$
Q=c W B \sqrt{2 g H}
$$

where $C$ is the orifice coefficient, typically taken as 0.8 and considered dimensionless. In practice, only the last 2 equations were applied to calculate the flow under the barrier. Based on integration of the calculated flows over time, the total sampled volume and glass eel densities could be calculated.

During sampling events 1 to 9, the 3 sampling techniques were applied simultaneously (Table 1). Lift net and stow net sampling started $3 \mathrm{~h}$ before high tide and ended at high tide. In some cases, the start of the stow net sampling was delayed because the tidal basin was not deep enough $3 \mathrm{~h}$ before high tide. In total, 931 lift net samples and 45 stow net samples were taken. On average, 21 lift net samples at each barrier and 5 stow net samples were taken during one sampling event. Fyke sampling started shortly before equalisation of the water levels at both sides of the barrier and ended at high tide. The fyke net was then lifted and emptied and glass eels were counted and kept in a reservoir. During 3 nocturnal sampling events (sampling events 7, 8 and 9), a second fyke, identical to the first one, was attached at the upstream side of a closed barrier of the mouth of the Yser River (Barrier 3; Fig. 1) to compare fyke net samples obtained with a closed barrier and with a barrier that was slightly opened $(0.1 \mathrm{~m})$. During the last 3 sampling events (sampling events 10 to 12), only fyke net samples were taken but glass eels were sampled during consecutive periods of $15 \mathrm{~min}$ (Table 1). The barrier was closed when the net was lifted and glass eels were counted. Fish processing time averaged $11 \mathrm{~min}$ and ranged between 5 and 20 min. To avoid sampling bias, all sampled glass eels were released upstream of the barriers after a period of acclimatisation.

\section{Data analysis}

First, we analysed the factors affecting glass eel attraction to the barriers, and then we assessed whether adjusted barrier management is a valid approach to restoring glass eel migration. The last research question was tested based on the fyke samples from the 12 sampling events. The first research question focused on both diurnal changes in glass eel density and on the factors affecting glass eel attraction to the barriers at night. To investigate diurnal glass eel density changes, the lift net, stow net and fyke net samples from sampling events 1 to 6 were analysed. Next, the factors affecting glass eel attraction to the barriers at night were assessed based on the lift net data from the first 6 nights (sampling events 2, 4, 6, 7, 8 and 9; 616 samples). Specifically, support-vector machines (SVMs) were applied to assess the effect of 4 variables on the glass eel densities observed with lift nets at the barriers: the sampling location, the sampling event, the time before high tide at which the sample was taken and the freshwater flow leaking from the barrier. There was no opportunity to test the impact of other factors such as wind direction, illumination, water quality or river bed structure directly downstream of the barrier as these factors showed no 
substantial variation during sampling. SVMs aim to find the optimal hyperplane that has at most a fixed deviation $(\varepsilon)$ from the observations and at the same time is as flat as possible (Vapnik 1995). They map the training set non-linearly into a higher dimensional feature space and then construct the optimal hyperplane in that feature space. In contrast to the linear decision boundaries applied by other techniques such as classification trees, this hyperplane is effectively a non-linear decision boundary in the input space. The algorithm that calculates the optimal hyperplane only considers those points in the training set that are relevant to the position of the boundary, the so-called support vectors. First, the SVM identifies the data points positioned on the boundary and approximates the hyperplane based on these data points. If the resulting model does not satisfy the maximum error threshold, the SVM identifies more boundary points and computes a new model until the threshold has been satisfied.

Data were analysed with the machine learning package WEKA 3.6.1 (Waikato Environment for Knowledge Analysis; Witten \& Frank 2000), which implements SVM algorithms. The Sequential Minimal Optimisation (SMO) algorithm for SVM regression was used with default settings (Witten \& Frank 2000), the parameters being learned with the optimisation algorithm of Shevade et al. (2000). To assess the robustness of the developed models, 3-fold crossvalidation and training set randomisation were applied on the nocturnal lift net sample data set with 616 instances. The models were evaluated based on the correlation coefficient between observations and model predictions, and $t$-tests and paired $t$-tests were applied for all other analyses.

\section{RESULTS}

\section{Factors affecting attraction to the barriers}

\author{
Diurnal changes in distribution
}

Average glass eel densities based on stow nets (Table 2) and lift nets (Fig. 2; $t$-test, $\mathrm{p}<0.001, \mathrm{n}=$ 931) were both significantly higher during night than during the day. Moreover, the maximal density observed during daytime did not exceed the minimal density observed at night. Nocturnal stow net densities were higher than those obtained from fyke net sampling but in contrast to the stow net densities, diurnal changes in fyke net densities were less obvious. Specifically, both the lowest and the highest fyke net glass eel density were observed during daytime (Table 2). During the nocturnal sampling events 2, 4, 6 and 8, glass eel density measured with stow nets showed a peak in the last hour before high tide (Fig. 3). This peak was not observed during daytime (sampling events 1, 3 and 5) and during sampling events 7 and 9 (Fig. 3). No significant correlation was found between the glass eel densities obtained by stow nets and lift net sampling at the barriers.

\section{Factors affecting nocturnal attraction}

SVM analysis of the densities observed by lift net sampling (Fig. 2) at the barriers indicated that the freshwater outflow leaking through the closed barriers had the strongest impact on glass eel densities (Table 3). Stepwise backward variable selection

Table 2. Anguilla anguilla. Total number and average $( \pm \mathrm{SD})$ densities of glass eels determined by lift, stow and fyke net sampling during 9 consecutive sampling events at the mouth of the Yser River. CIs for lift and stow net densities were based on the standard deviation

\begin{tabular}{|c|c|c|c|c|c|c|}
\hline \multirow{2}{*}{$\begin{array}{l}\text { Sampling } \\
\text { event }\end{array}$} & \multicolumn{2}{|c|}{$\longrightarrow$ Lift net } & \multicolumn{2}{|c|}{$\longrightarrow$ Stow net } & \multicolumn{2}{|c|}{-Fyke net } \\
\hline & $\begin{array}{l}\text { No. of } \\
\text { glass eel }\end{array}$ & $\begin{array}{l}\text { Glass eel density } \\
\text { (ind. } \mathrm{m}^{-3} \text { ) }\end{array}$ & $\begin{array}{l}\text { No. of } \\
\text { glass eel }\end{array}$ & $\begin{array}{l}\text { Glass eel density } \\
\text { (ind. } \mathrm{m}^{-3} \text { ) }\end{array}$ & $\begin{array}{l}\text { No. of } \\
\text { glass eel }\end{array}$ & $\begin{array}{l}\text { Glass eel density } \\
\text { (ind. } \mathrm{m}^{-3} \text { ) }\end{array}$ \\
\hline $1^{\mathrm{a}}$ & 30 & $0.071 \pm 0.143$ & 22 & $0.007 \pm 0.006$ & 238 & 0.029 \\
\hline 2 & 241 & $1.162 \pm 1.838$ & 1157 & $0.359 \pm 0.225$ & 590 & 0.087 \\
\hline $3^{\mathrm{a}}$ & 18 & $0.049 \pm 0.118$ & 15 & $0.005 \pm 0.002$ & 430 & 0.047 \\
\hline 4 & 129 & $0.521 \pm 0.738$ & 758 & $0.272 \pm 0.113$ & 937 & 0.121 \\
\hline $5^{\mathrm{a}}$ & 37 & $0.100 \pm 0.186$ & 6 & $0.002 \pm 0.002$ & 1496 & 0.202 \\
\hline 6 & 149 & $0.615 \pm 0.893$ & 970 & $0.379 \pm 0.127$ & 737 & 0.129 \\
\hline 7 & 366 & $1.065 \pm 1.635$ & 656 & $0.259 \pm 0.043$ & 657 & 0.09 \\
\hline 8 & 217 & $0.720 \pm 1.824$ & 916 & $0.415 \pm 0.174$ & 308 & 0.041 \\
\hline 9 & 284 & $0.943 \pm 1.464$ & 729 & $0.250 \pm 0.037$ & 823 & 0.122 \\
\hline
\end{tabular}




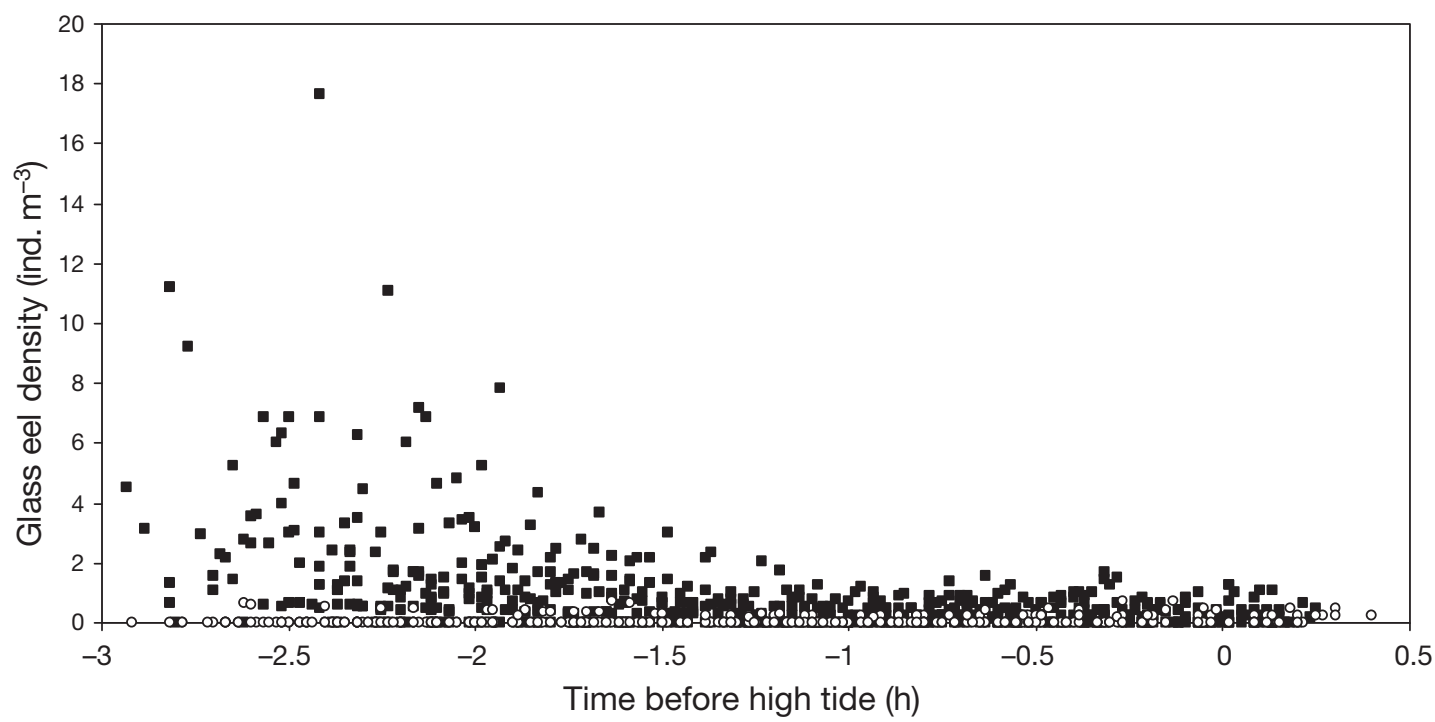

Fig. 2. Anguilla anguilla. Glass eel densities observed with lift nets at different times during the tidal rise of the first 9 sampling events, which were taken during the day (O) or at night (

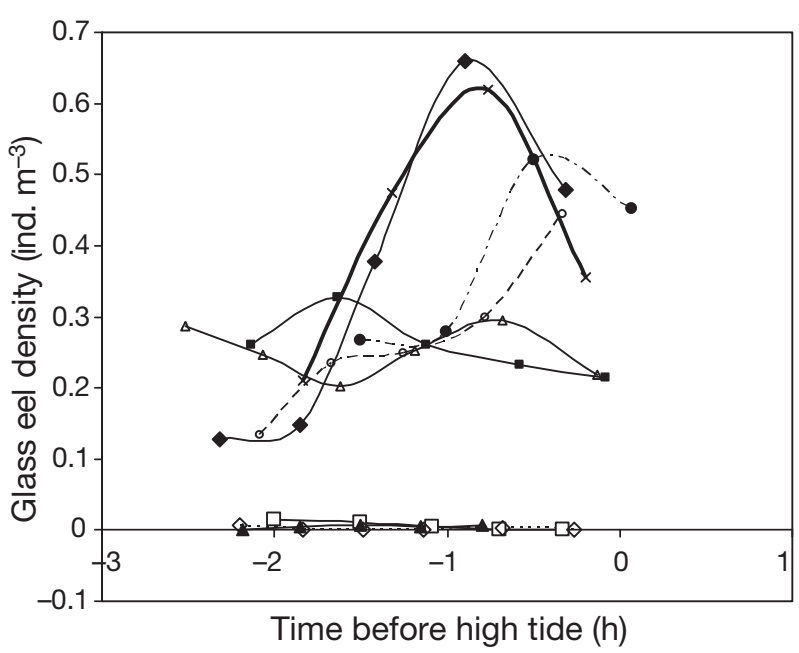

\begin{tabular}{|c|c|}
\hline \begin{tabular}{r}
$\square-$ Sampling event 1 \\
$\multimap$ Sampling event 2 \\
\hdashline- Sampling event 3 \\
$\ldots \diamond-$ Sampling event 4 \\
Sampling event 5
\end{tabular} & $\begin{array}{l}\longrightarrow \text { - Sampling event } 6 \\
\longrightarrow \text { Sampling event } 7 \\
\longrightarrow \text { Sampling event } 8 \\
\longrightarrow \text { Sampling event } 9\end{array}$ \\
\hline
\end{tabular}

Fig. 3. Anguilla anguilla. Glass eel densities observed with stow nets at different times during the tidal rise of the first 9 sampling events. Sampling events 1, 3 and 5 occurred during daytime, whereas all other sampling events were nocturnal

showed that the sampling location and the time before high tide had weak effects on glass eel densities (Table 3). Specifically, the latter variable could be omitted from the model without any sig- nificant reduction in model performance. The limited impact of temporal variables indicated the collected data were not strongly temporally autocorrelated.

\section{Impact of adjusted barrier management}

During the closed barrier samplings, only $2.67 \pm$ 2.08 (mean $\pm \mathrm{SD}$ ) glass eels per tidal cycle were caught, whereas $632.18 \pm 367.71$ glass eels per tidal cyclewere caught during the opened barrier samplings. In total, 6216 glass eels migrated upstream during the first 9 fyke net sampling events. Given a low, average and peak flow of $1.57 \mathrm{~m}^{3} \mathrm{~s}^{-1}, 6.09 \mathrm{~m}^{3} \mathrm{~s}^{-1}$ and $20.37 \mathrm{~m}^{3} \mathrm{~s}^{-1}$, respectively, during the glass eel migration period (March to April) in the Yser River, the upstream inflow of seawater would average $2.8 \%$ and range between 0.7 and $13.2 \%$ of the daily discharge if the barrier were opened during every tidal rise.

The upstream glass eel migration was observed in detail by fyke net sampling in short time intervals during the last 3 sampling events (Fig. 4). Glass eel density generally peaked within $1 \mathrm{~h}$ after equalisation of the water levels at both sides of the barrier and within $1.5 \mathrm{~h}$ before high tide. Glass eel densities decreased around high tide, slightly recovered at least $1 \mathrm{~h}$ after high tide and appeared to reach a minimum at $3.5 \mathrm{~h}$ post equalisation. Although the glass eel densities showed similar trends, absolute densities differed between different sampling events. 
Table 3. Results of the stepwise backward variable selection procedure assessing the impact of 4 variables on glass eel densities observed at night at the barriers with lift net sampling (no. of instances $=616$ ). The stepwise backward procedure started with a model including all variables (Model 1) and then eliminated the least significant variable until a single variable model was obtained (Model 4). Variable rankings and average $( \pm \mathrm{SD})$ weights of 4 models are given with their correlation coefficients, which indicate average performance of these models. For categorical variables, the highest weight was selected

\begin{tabular}{|lcccc|}
\hline Rank (Weight) & Model 1 & Model 2 & Model 3 & Model 4 \\
\hline Freshwater flow & $1(0.280 \pm 0.002)$ & $1(0.326 \pm 0.006)$ & $1(0.396 \pm 0.001)$ & $1(0.269 \pm 0.001)$ \\
Time before high tide & $2(0.097 \pm 0.001)$ & $3(0.058 \pm 0.005)$ & Removed & Removed \\
Sampling location & $3(0.054 \pm 0.001)$ & $2(0.062 \pm 0.001)$ & $2(0.066 \pm 0.001)$ & Removed \\
Sampling event & $4(0.051 \pm 0.000)$ & Removed & Removed & Removed \\
Correlation coefficient & $0.606 \pm 0.009$ & $0.606 \pm 0.010$ & $0.598 \pm 0.017$ & $0.435 \pm 0.019$ \\
\hline
\end{tabular}

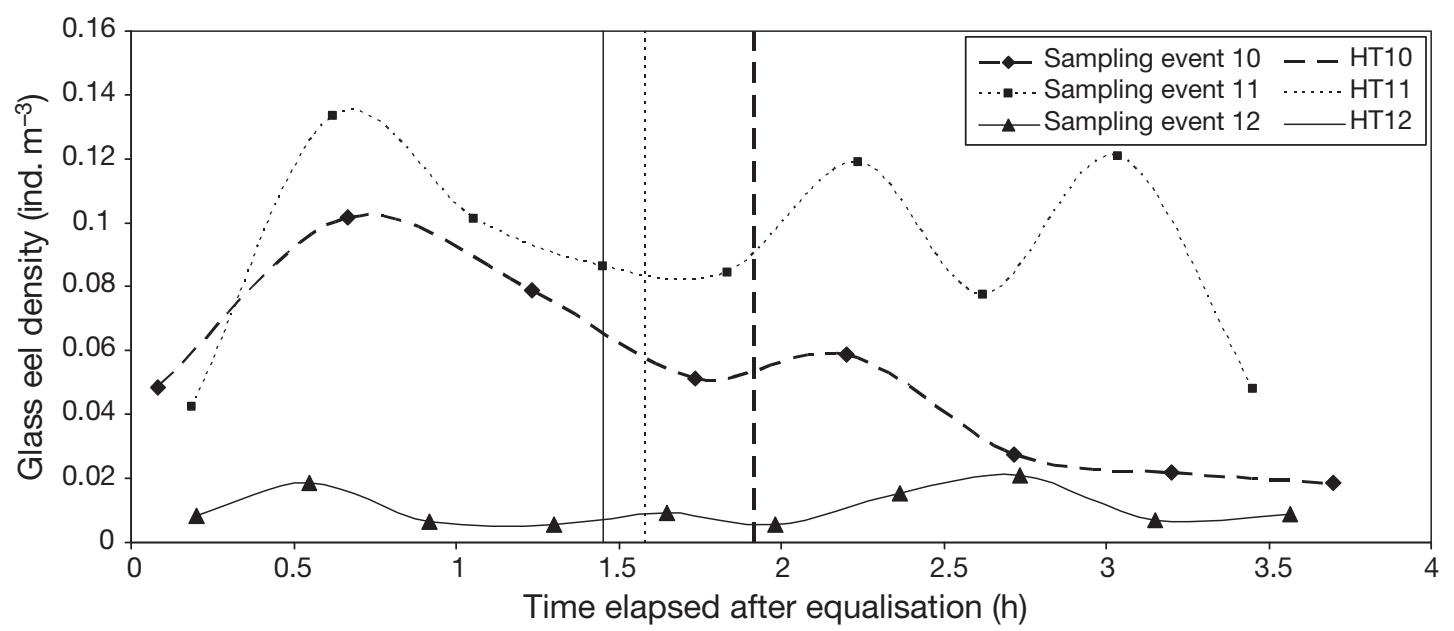

Fig. 4. Anguilla anguilla. Glass eel densities observed by fyke net sampling during tidal rise at a slightly opened barrier (0.1 m) during the last 3 consecutive nocturnal sampling events (sampling events 10 to 12). Sampling was started after the water level downstream of the barrier was approximately equal to that upstream (equalisation) and conducted for consecutive 15 min durations. For each sampling event, the time of high tide (HT) is indicated by a vertical line and HT numbers correspond with sampling events

\section{DISCUSSION}

\section{Factors affecting attraction to the barriers}

Diurnal changes in distribution

These results confirm the negative phototactical behaviour of glass eels (de Casamajor et al. 1999, Bardonnet et al. 2005) because the difference in glass eel density between both diurnal and nocturnal samples was higher for the stow net observations than for the lift net samples. Specifically, during daytime glass eels appeared to avoid the upper $0.5 \mathrm{~m}$ of the water column that was sampled by the stow nets. This is in line with previous research indicating that most glass eels frequent this layer at night (de Casamajor et al. 1999). Further research could reveal more detailed information on the diurnal patterns of glass eel distribution. However, our results show that despite their negative phototactical behaviour, glass eels are present both during daytime and at night. Specifically, the fyke net densities appear to be less dependent on diurnal changes and thus the adjusted barrier management could be applied continuously during the glass eel migration period.

\section{Factors affecting nocturnal attraction}

Although the SVM analysis of the lift net samples revealed only a weak effect of the time before high tide on glass eel densities, the stow net samples (Fig. 3) suggest that nocturnal glass eel densities in the tidal basin may peak in the last hour before high 
tide. Because all samplings occurred during similar conditions of illumination, a phototaxis effect is not likely and thus these results may indicate that most glass eels transported with the tidal stream arrive at the river mouth during the last hour before high tide. This is in line with previous research that analysed upstream migration of European glass eels at an estuarine dam (Laffaille et al. 2007, Crivelli et al. 2008). However, the lack of correlation between lift and stow net densities may indicate that most of the glass eels attempting to migrate past the barriers during the rising tide had arrived on a previous tidal cycle or that glass eels had failed in a previous attempt to pass the barriers.

The limited effect of the sampling location indicates that glass eels succeed in withstanding strong flow conditions at low tide. Specifically, substantial differences in discharge at low tide were observed between the 5 sampling locations (www.waterstanden.be) and as already mentioned, many of the glass eels attempting to migrate past a barrier during the rising tide may have arrived during a previous tidal cycle. Consequently, the observations suggest that the strong flow conditions did not cause significant drift of glass eels. Since the stony river bed substrate downstream of the barriers provides substantial cover habitat, this may indeed avoid glass eel drift. Further, the lack of an effect from sampling location also underlines that river management should focus on all barriers given similar river habitat conditions upstream of the barriers. The presented results also indicate the limited influence of complex flow conditions in the river section downstream of the barriers, thus suggesting active migration of glass eels towards the tidal barriers. Specifically, based on selective tidal stream transport (Creutzberg 1959, McCleave \& Kleckner 1982), most glass eels are expected to occur at the barriers that are located in the direction of the tidal stream (Locations 1 to 3; Fig. 1). However, no significant difference in glass eel densities was observed at the 5 sampling locations and thus glass eels may migrate actively towards these barriers, which matches the results of Bureau Du Colombier et al. (2007).

These results showed that glass eels migrated towards barriers based on the presence of a freshwater flow attracting them. A similar positive influence of freshwater flow has been observed in American glass eel Anguilla rostrata (Lesueur) (Sullivan et al. 2006). Whether the positive effect of the freshwater flow on glass eel densities is caused by the salinity difference or the increased current is unclear. However, the latter is less likely because the freshwater flow is dif- fused across the whole barrier and thus substantial flow rates were absent during sampling. Consequently, the limited and diffuse freshwater flow that was leaking from the barriers appeared to be appropriate to attract glass eels. Previous research has shown that stronger downstream attraction flows may induce positive rheotaxis in glass eels and thus increase energy consumption (Bolliet et al. 2007, Bureau Du Colombier et al. 2009). In contrast, the upstream inflow of seawater at a slightly opened barrier might facilitate passive glass eel drift and avoid unnecessary energy loss. This energetic advantage may favour the suggested management option over other options such as eelways (Edeline et al. 2006, Bureau Du Colombier et al. 2007).

\section{Impact of adjusted barrier management}

The comparison of fyke net samples obtained with a closed barrier and those with a slightly opened barrier clearly demonstrated that tidal barriers substantially limit the upstream migration of glass eels. The results of the fyke net sampling with an opened barrier indicate that adjusted barrier management may overcome this problem. Although the limited barrier opening appears to be a cost-efficient and effective management option, its single disadvantage could be the upstream influx of seawater. Specifically, stakeholders may wish to avoid agricultural, environmental or recreational problems associated with such salt water intrusion. The presented detailed observations on the upstream migration of glass eels at opened barriers (sampling events 10 to 12 ) showed that a migration peak generally occurs shortly after equalisation of water levels at both sides of the barrier and within $1.5 \mathrm{~h}$ before high tide. This is in line with the density peak observed with nocturnal stow net sampling, although the stow net density peak appears to occur closer to high tide (Fig. 3) and the average stow net densities appeared to be independent from the fyke net densities (Table 2). Based on these results, the adjusted barrier management could thus be applied during a smaller time frame to improve upstream migration of glass eels if inflow of seawater was a major concern. However, the results also emphasize that given a continuously adjusted barrier management strategy, the seawater inflow is limited and most of the seawater would be washed out again once the barrier is opened at low tide. This possibility was emphasized by conductivity measurements during application of the adjusted barrier management one year after our 
study. Conductivity was continuously monitored between February and June 2010 at 2 sites 1 and $5 \mathrm{~km}$ upstream of the Yser River barrier. Although the adjusted barrier management was applied between February and May, no conductivity increase was observed (INBO unpubl. data).

Further research could focus on fine tuning the presented adjusted barrier management. Specifically, the fyke net experiments in this study were only conducted at one barrier of one river mouth. The impact of adjusted barrier management at different barriers in the same river mouth or at different river mouths could be studied to further optimise the suggested approach. Moreover, long-term fyke net monitoring may also indicate if there is a temporal threshold at which most glass eels have migrated upstream. Finally, future research could explore the effectiveness of recently developed solutions to allow fish migration at tidal barriers, such as tidal flaps.

This work emphasizes the negative effects of tidal barriers on upstream glass eel migration and shows that adjusted barrier management may be a costeffective and efficient mitigation option. Within the studied area, this option may improve glass eel migration at all river mouths, given the rather uniform distribution of glass eels over the different river mouths. Future research could optimise the adjusted barrier management and thus improve the efficiency of the presented approach. Further, the impact of the adjusted management on eel densities in the Yser basin could be assessed. Adjusted barrier management could be implemented and applied on numerous tidal barriers. Therefore the results of this paper are of interest to a wide range of river managers and stakeholders and may contribute to the conservation of many eel populations.

Acknowledgements. This research was funded by Waterwegen en Zeekanaal NV and by the Interreg IVb North Sea Region Programme project 'Living North Sea' (www.livingnorthsea.eu). E. Gelaude, R. Baeyens, S. Martens and Y. Jacobs assisted with the data collection. The authors thank the anonymous reviewers for their valuable suggestions that improved the manuscript.

\section{LITERATURE CITED}

Audenaert V, Huyse T, Goemans G, Belpaire C, Volckaert FAM (2003) Spatio-temporal dynamics of the parasitic nematode Anguillicola crassus in Flanders, Belgium. Dis Aquat Org 56:223-233

Bardonnet A, Bolliet V, Belon V (2005) Recruitment abundance estimation: role of glass eel (Anguilla anguilla L.) response to light. J Exp Mar Biol Ecol 321:181-190

Bolliet V, Lambert P, Rives J, Bardonnet A (2007) Rhythmic swimming activity in Anguilla anguilla glass eels: synchronisation to water current reversal under laboratory conditions. J Exp Mar Biol Ecol 344:54-66

Bonhommeau S, Chassot E, Planque B, Rivot E, Knap AH, Le Pape O (2008a) Impact of climate on eel populations of the Northern Hemisphere. Mar Ecol Prog Ser 373:71-80

> Bonhommeau S, Chassot E, Rivot E (2008b) Fluctuations in European eel (Anguilla anguilla) recruitment resulting from environmental changes in the Sargasso Sea. Fish Oceanogr 17:32-44

Briand C, Fatin D, Fontenelle G, Feunteun E (2005) Effect of re-opening of a migratory pathway for eel (Anguilla anguilla, L.) at a watershed scale. Bull Fr Peche Piscic 378-379:67-86

> Bult TP, Dekker W (2007) Experimental field study on the migratory behaviour of glass eels (Anguilla anguilla) at the interface of fresh and salt water. ICES J Mar Sci 64: 1396-1401

Buysse D, Coeck J, Maes J (2008) Potential re-establishment of diadromous fish species in the River Scheldt (Belgium). Hydrobiologia 602:155-159

$>$ Creutzberg F (1959) Discrimination between ebb and flood tide in migrating elvers (Anguilla vulgaris, Turt.) by means of olfactory perception. Nature 184:1961-1962

> Crivelli AJ, Auphan N, Chauvelon P, Sandoz A, Menella JY, Poizat G (2008) Glass eel recruitment, Anguilla anguilla (L.), in a Mediterranean lagoon assessed by a glass eel trap: factors explaining the catches. Hydrobiologia 602: 79-86

de Casamajor MN, Bru N, Prouzet P (1999) Influence of night brightness and turbidity on the vertical migratory behaviour of glass-eels (Anguilla anguilla L.) in the Adour estuary. Bull Fr Peche Piscic 355:327-347

Dekker W (1998) Long-term trends in the glasseels immigrating at Den Oever, the Netherlands. Bull Fr Peche Piscic 349:199-214

Dekker W (2000) The fractal geometry of the European eel stock. ICES J Mar Sci 57:109-121

Denayer B, Belpaire C (1996) Bottle-necks for restoration of the eel population, Anguilla anguilla (L.) of the River Yser basin (Flanders). Arch Pol Fish 4:175-186

Bureau Du Colombier S, Bolliet V, Lambert P, Bardonnet A (2007) Energy and migratory behavior in glass eels (Anguilla anguilla). Physiol Behav 92:684-690

> Bureau Du Colombier S, Bolliet V, Bardonnet A (2009) Swimming activity and behaviour of European Anguilla anguilla glass eels in response to photoperiod and flow reversal and the role of energy status. J Fish Biol 74: 2002-2013

> Edeline E, Dufour S, Elie P (2005) Role of glass eel salinity preference in the control of habitat selection and growth plasticity in Anguilla anguilla. Mar Ecol Prog Ser 304: 191-199

Edeline E, Lambert P, Rigaud C, Elie P (2006) Effects of body condition and water temperature on Anguilla anguilla glass eel migratory behavior. J Exp Mar Biol Ecol 331: $217-225$

$>$ Feunteun E, Acou A, Guillouët J, Laffaille P, Legault A (1998) Spatial distribution of an eel population (Anguilla anguilla L.) in a small coastal catchment of northern Brittany (France). Consequences of hydraulic works. Bull Fr Peche Piscic 349:129-139

Friedland KD, Miller MJ, Knights B (2007) Oceanic changes in the Sargasso Sea and declines in recruitment of the European eel. ICES J Mar Sci 64:519-530 
Kettle AJ, Bakker DCE, Haines K (2008) Impact of the North Atlantic Oscillation on the trans-Atlantic migrations of the European eel (Anguilla anguilla). J Geophys Res 113: G03004

Knights B (2003) A review of the possible impacts of longterm oceanic and climate changes and fishing mortality on recruitment of anguillid eels of the Northern Hemisphere. Sci Total Environ 310:237-244

Laffaille P, Caraguel JM, Legault A (2007) Temporal patterns in the upstream migration of European glass eels (Anguilla anguilla) at the Couesnon estuarine dam. Estuar Coast Shelf Sci 73:81-90

McCleave JD, Kleckner RC (1982) Selective tidal stream transport in the estuarine migration of glass eels of the American eel (Anguilla rostrata). J Cons Int Explor Mer 40:262-271

Shevade SK, Keerthi SS, Bhattacharyya C, Murthy KRK (2000) Improvements to the SMO algorithm for SVM regression. IEEE Trans Neural Network 11: 1188-1193

Stevens M, Coeck J, van Vessem J (2009) Wetenschappelijke onderbouwing van de palingbeheerplannen voor

Editorial responsibility: Matthias Seaman,

Oldendorf/Luhe, Germany
Vlaanderen. Instituut voor Natuur- en Bosonderzoek, Brussels

Sullivan MC, Able KW, Hare JA, Walsh HJ (2006) Anguilla rostrata glass eel ingress into two US east coast estuaries: patterns, processes and implications for adult abundance. J Fish Biol 69:1081-1101

Vapnik VN (1995) The nature of statistical learning theory. Springer Verlag, Berlin

White EM, Knights B (1997) Environmental factors affecting migration of the European eel in the Rivers Severn and Avon, England. J Fish Biol 50:1104-1116

> Wilson JM, Antunes JC, Bouça PD, Coimbra J (2004) Osmoregulatory plasticity of the glass eel of Anguilla anguilla: freshwater entry and changes in branchial ion-transport protein expression. Can J Fish Aquat Sci 61:432-442

Wilson JM, Leitão A, Gonçalves AF, Ferreira C and others (2007) Modulation of branchial ion transport protein expression by salinity in glass eels (Anguilla anguilla L.). Mar Biol 151:1633-1645

Witten IH, Frank E (2000) Data mining: practical machine learning tools and techniques with Java implementations. Academic Press, San Diego, CA

Submitted: January 17, 2010; Accepted: July 27, 2011

Proofs received from author(s): September 29, 2011 